\title{
WATER RESOURCES ANALYSIS OF THE RJEČINA KARST SPRING AND RIVER (DINARIC KARST)
}

\author{
ANALIZA VODNIH VIROV KRAŠKEGA IZVIRA IN REKE RJEČINA \\ (DINARSKI KRAS)
}

\author{
Ognjen BONACCI ${ }^{1, *}$, Maja OŠTRIĆ ${ }^{2} \&$ Tanja ROJE-BONACCI ${ }^{2}$
}

\begin{abstract}
UDC 551.444.3:556.3(497.561)

Ognjen Bonacci, Maja Oštrić \& Tanja Roje-Bonacci: Water resources analysis of the Rječina karst spring and river (Dinaric karst)

The paper deals with complex hydrological/hydrogeological behaviour in the Rječina karst spring and river basin located in the north-western part of the deep and developed Croatian Dinaric karst. The Rječina Spring is one of the major karst springs in Croatia, used for water supply of Rijeka City and its surrounding area. Beside the use of Rječina spring for water supply, the development of the Rijeka hydroelectric power plant (HEPP) also changed hydrological and hydrogeological regime of the whole catchment. In order to analyse the anthropogenic influences in the system, hydrological analysis of the Rječina river and spring discharge was done, as well as the analysis of the available data of groundwater measurements. The analysis showed that, due to the increase of water caption and decrease of precipitation, the average annual spring discharge decreased for approximately $25 \%$ in the $1980-2016$ period. Detailed analysis of groundwater measurements indicated aquifer behaviour and the need for additional measurements and catchment delineation.
\end{abstract}

Key words: hydrology, hydrogeology, karst, Rječina Spring, Rječina River, Dinaric karst.
Izvleček UDK 551.444.3:556.3(497.561)

Ognjen Bonacci, Maja Oštrić \& Tanja Roje-Bonacci: Analiza vodnih virov kraškega izvira in reke Rječina (Dinarski kras)

Članek obravnava zapletene hidrološke/hidrogeološke razmere v zaledju kraškega izvira in reke Riečine v severozahodnem delu globokega in dobro razvitega hrvaškega Dinarskega krasa. Izvir Rječina je eden največjih kraških izvirov na Hrvaškem, zajet je za oskrbo s pitno vodo za mesto Reka in njeno okolico. Poleg rabe izvira Rječine za oskrbo z vodo je razlog za spremenjen hidrološki in hidrogeološki režim celotnega zaledja tudi gradnja hidroelektrarne Reka (HEPP). Za analizo antropogenih vplivov na sistem smo zato naredili hidrološko analizo pretokov reke in izvira Rječina pa tudi analizo razpoložljivih podatkov merjenja podzemne vode. Analiza je pokazala, da se je zaradi povečanja zajemanja vode in zmanjšanja količine padavin povprečen letni pretok izvira v obdobju 1980-2016 zmanjšal za približno $25 \%$. Podrobna analiza meritev podzemne vode je nakazala značilnosti delovanja vodonosnika ter pokazala potrebo po dodatnih meritvah in določitvi zaledja izvira.

Ključne besede: hidrologija, hidrogeologija, kras, izvir Rječina, reka Rječina, Dinarski kras.

\footnotetext{
${ }^{1}$ Split University, Faculty of Civil Engineering, Architecture and Geodesy, 21000 Split, Matice hrvatske 15, Croatia, e-mail: obonacci@gradst.hr

${ }^{2}$ Hrvatske vode, 51000 Rijeka, Đure Šporera 3, Croatia, e-mail: maja.ostric@voda.hr

${ }^{3}$ Split University, Faculty of Civil Engineering, Architecture and Geodesy, 21000 Split, Matice hrvatske 15, Croatia, e-mail: bonacci@gradst.hr,

* Corresponding author
}

Received/Prejeto: 31.08.2017 


\section{INTRODUCTION}

Karst covers a vast area worldwide with various formations and evolution. Rich water resources as well as other valuable resources can be found (e.g., Floridan aquifer, Dinaric karst aquifer system) in planetary karst areas. Complex, dynamic and vulnerable karst system is a part of the Earth's system, sensitive to climate, environmental changes and human influence. Karst water resources provide drinking water for nearly $25 \%$ of the world population (Ford \& Williams 2007), while in the USA up to $40 \%$ of water supply is from karst water and in some European countries 50 $\%$ (Goldscheider 2005). There are many human activities that, intentionally or not, produce severe impacts on karst, often with irreparable damage (e.g., Calò \& Parise 2006; Parise \& Gunn 2007).

Although karst aquifers have a huge importance to water supply in many countries, due to the high discharge variations and vulnerability to pollution they are sometimes difficult to use (Goldscheider 2005; Brkic et al. 2018). The highest lack of water occurs during summer period due to the low amount of precipitation and high evapotranspiration (Zupan Hajna et al. 2010). The most usual sources of contamination are urban settlements, industry, agriculture and traffic (Petrič et al. 2011; Kogovšek 2011). Beside the use of water for water supply, it is also used for irrigation and flood control, but the main impact on the karst has the use of waters in hydropower stations (Zupan Hajna et al. 2010) In karst terrains, groundwater and surface water constitute a single dynamic system. Determination of the catchment area and boundaries in karst environment presents an extremely difficult and complex task, which very often remains unsolved. The interdependency between surface water and groundwater in karst occasionally or permanently changes in time and space. These changes are caused by natural processes (intensive and abundant precipitations, collapse of surface and underground karst features, breaking out of clay clogs formed in karst conduits, etc.) as well as anthropogenic interventions, which have been very intensive in the last hundred years or so and are generally uncontrolled.

This paper presents a hydrological and hydrogeological analysis of a complex karst Rječina River and Spring catchment, that are located in deep and developed Dinaric karst. The Rječina River basin is located in the north-western part of the Croatian Dinaric karst. This karst system is of crucial importance for the town of Rijeka and its broader surrounding. Rijeka is the principal seaport and the third largest city in Croatia, located in the Kvarner Bay of the Adriatic Sea with a population of 128,624 inhabitants, according to the population census from 2011. The metropolitan area has a population of more than 240,000. Tourism causes high seasonal water needs.

The main objective of this paper was to perform hydrological and hydrogeological analysis of a complex karst Rječina River and Spring catchment in order to indicate the impact of the water use of Rječina Spring in water supply and use of water of Rječina River for hydropower plant (HEPP).

\section{STUDY AREA GEOLOGY, HYDROGEOLOGY AND CLIMATOLOGY}

The study area is located in the north-western part of the Dinaric karst in Croatia between $45^{\circ} 40^{\prime}$ and $45^{\circ} 15^{\prime} \mathrm{N}$ and $14^{\circ} 20^{\prime}$ and $14^{\circ} 30^{\prime}$ E. Fig. 1 shows a location map of the study area indicating the Rječina River and Spring, Zvir Spring, Zvir 2 Intake gallery, few other springs in the catchment, Rijeka meteorological station, Marčelji rain gauging station, Rijeka hydroelectric power plant (HEPP), Valići Reservoir, planned Kukuljani Reservoir, locations of nine deep piezometers (P1, P2, P2B, P3, P4, P5, B1, B2, B3) and seven hydrological gauging stations. Piezometers $\mathrm{P} 2$ and $\mathrm{P} 2 \mathrm{~B}$ are located within $10 \mathrm{~m}$ of distance and due to the scale of map it is not possible to show them separately, but instead two labels are placed on location of one piezometer.

The main sources for water supply of Rijeka and a wider area are Rječina Spring and Zvir. Rječina Spring is used during most part of the year due to the hypsometric position that enables gravitational water supply of the city but it dries out in a summer period. In that period, permanent spring Zvir and intake gallery Zvir II are used for water supply. Maximal capacity of Rječina Spring as well as the Zvir Spring (installed capacity) is 2000 l/s. Intake gallery Zvir II was constructed close to the spring Zvir in the 1982 as a tunnel with 6 wells of $12 \mathrm{~m}$ depth. Zvir II with capacity of $600 \mathrm{l} / \mathrm{s}$ is used only occasionally, in very dry seasons, when permanent spring Zvir drops its capacity. HEPP system Rijeka was built on Rječina river in 1968 with Valići reservoir $\left(\mathrm{V}=0.6{ }^{*} 10^{6} \mathrm{~m}^{3}\right)$ and installed capacity of $36.8 \mathrm{MW}$. 


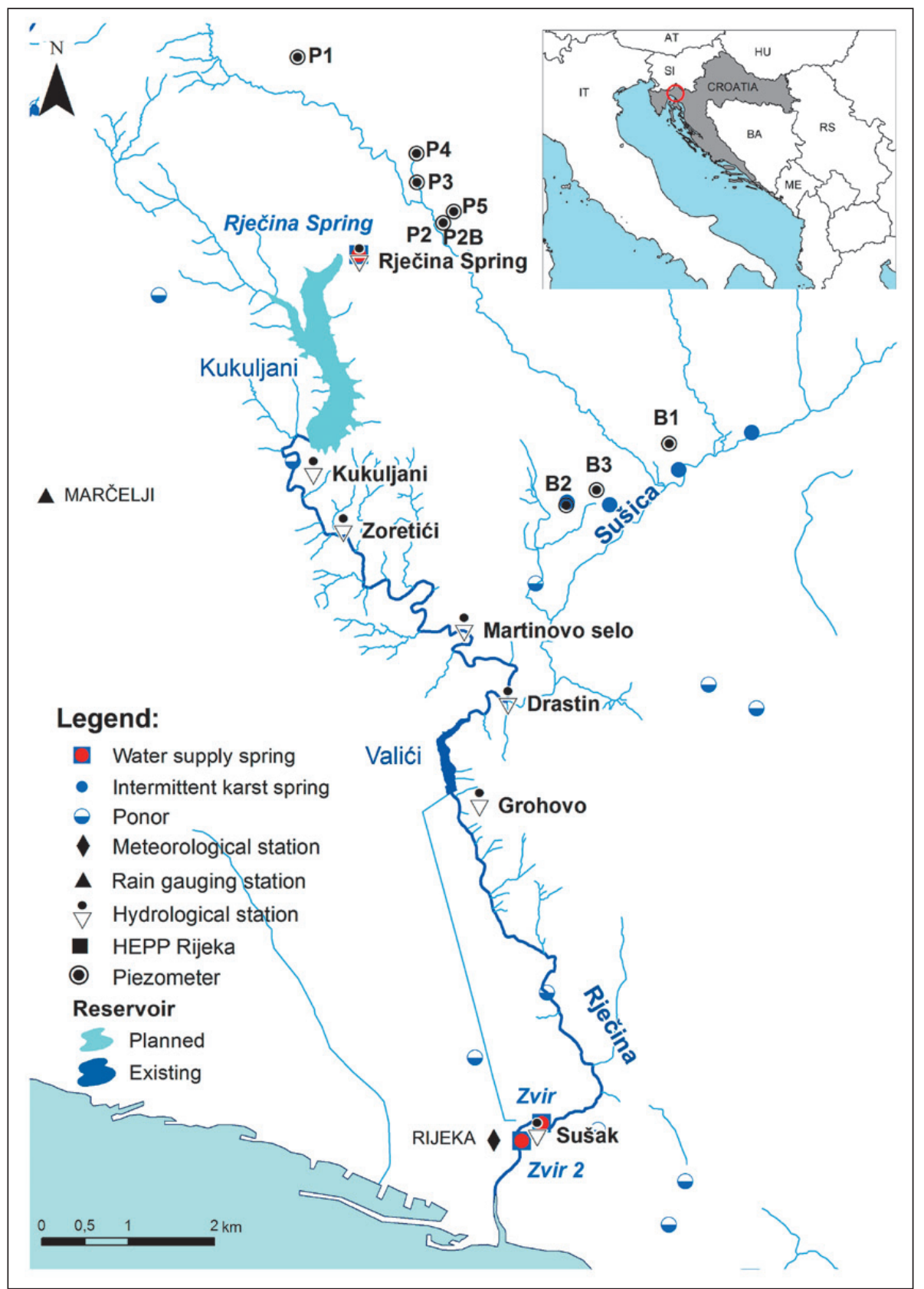

Fig. 1: Study area indicating Rječina River and Spring, Zvir Spring, Zvir 2 Spring, few other springs in the catchment and neighbouring area, Rijeka meteorological station, Marčelji rain gauging station, Rijeka hydroelectric power plant (HEPP), Valići Reservoir, planned Kukuljani Reservoir.

Fig. 2 shows results of tracer tests, and four hydrogeological units. This is a well-developed karst system with well-developed groundwater flow, where also surface flow occurs on low permeable deposits (Fig. 2). Within the studied area, the aquifer is composed of: (1) well permeable group of deposits (dark green in Fig 2.), mostly Upper Cretaceous $\left(\mathrm{K}_{2}\right)$ and Palaeogene limestone $\left(\mathrm{E}_{1,2}\right),(2)$ medium permeable rocks, mostly Lower Cretaceous $\left(\mathrm{K}_{1,2}\right)$ limestone and dolomites, (3) very low permeable Palaeogene flysch $\left(\mathrm{E}_{2,3}\right)$ that forms a barrier to groundwater flow and (4) Quaternary sediments (Q) of different permeability. Quaternary deposits are very important for understanding of the surface and groundwater system in the area and have a role in groundwater retention and flow. Grobnik Polje is a depression composed of Quaternary deposits, with numerous intermittent karst springs as well as ponors, occurring on its outskirts. Ponors mostly occur in the southern part of Grobnik Polje, while intermittent springs occur in its northern part (Fig. 2). The wider area of the Rječina River valley is part of a dominant morphostructural unit, which strikes in the direction of the Rječina river valley - Bakar Bay - Vinodol Valley (Velić \& Vlahović 2009). This geologic structure could be considered as a Palaeogene flysch syn- 


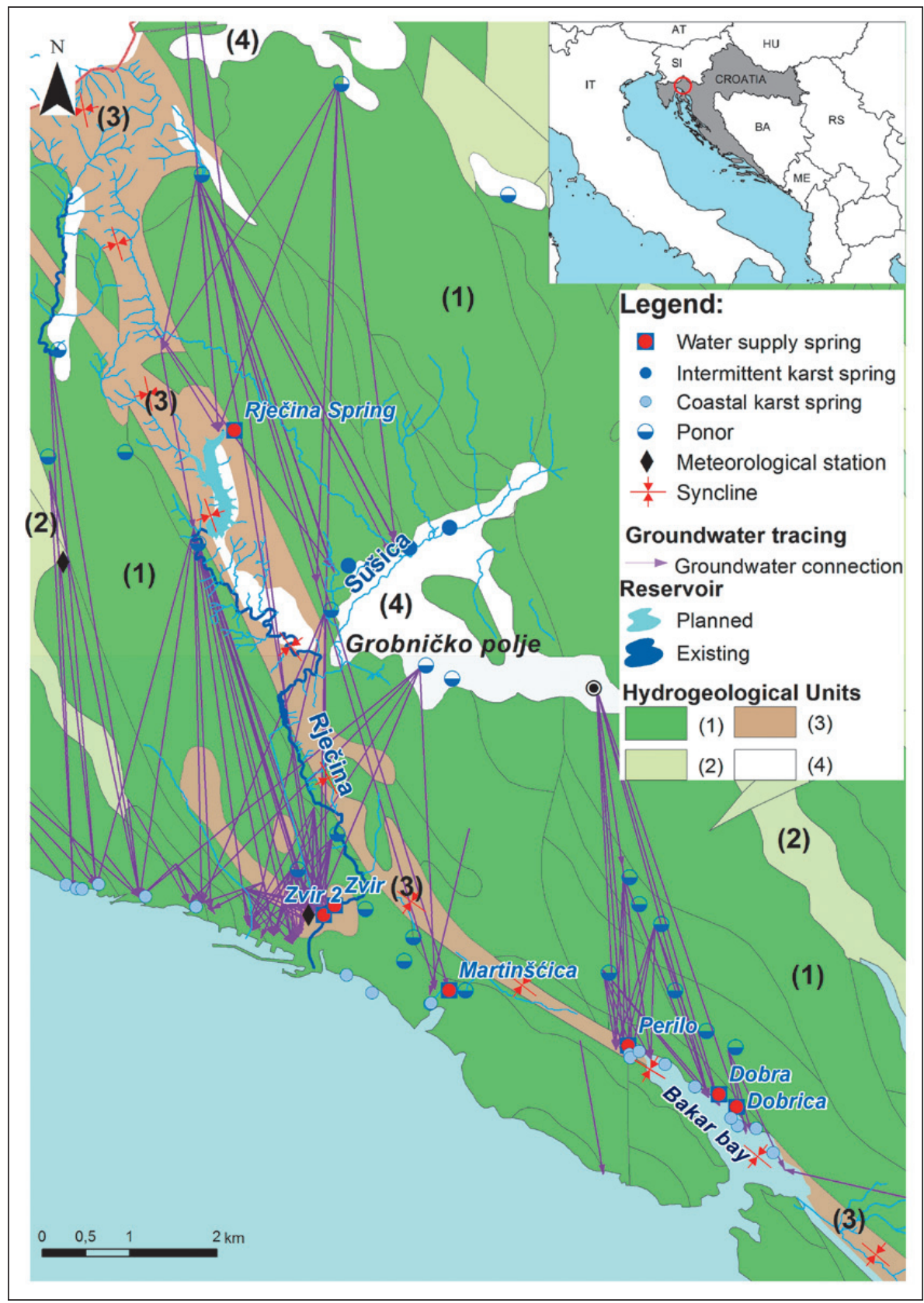

Fig. 2: Study area indicating results of tracer tests and four hydrogeological units: (1) well permeable carbonate rocks, (2) medium permeable carbonate rocks, (3) very low permeable flysch deposits, (4) Quaternary, low permeable deposits. (Simplified hydrogeological map and tracer tests results from data base of Croatian waters).

cline limited by faults (Benac et al. 2011). The syncline indicated in the Fig. 2 is an important structure that has a huge impact on hydrogeology of the study area. The syncline is striking from Slovenia to the coastline of Novi Vinodolski (more to SE, outside of the Fig. 2), with the submerged part in the Bakar Bay. The flysch sediments generally have very low permeability and depending on their structural position, they represent a hydrogeological barrier to groundwater flow in karst areas. The spatial distribution of flysch deposits affects the development of hydrologic network as well as the occurrence of the springs in the area.
A complex undiscovered underground system composed of conduits, cavities and caves is an inherent characteristic of the analysed environment. Groundwater and surface water are hydraulically connected through numerous karst forms which facilitate the exchange of water between the surface and subsurface as well as between neighbouring karst aquifers and catchments.

In karst terrains, one of the basic data for characterization of hydrogeological characteristics of the aquifer, and determination of groundwater flow direction and recharge area is obtained by groundwater tracer tests. The results of numerous tracer tests, given in Fig. 2, point to 


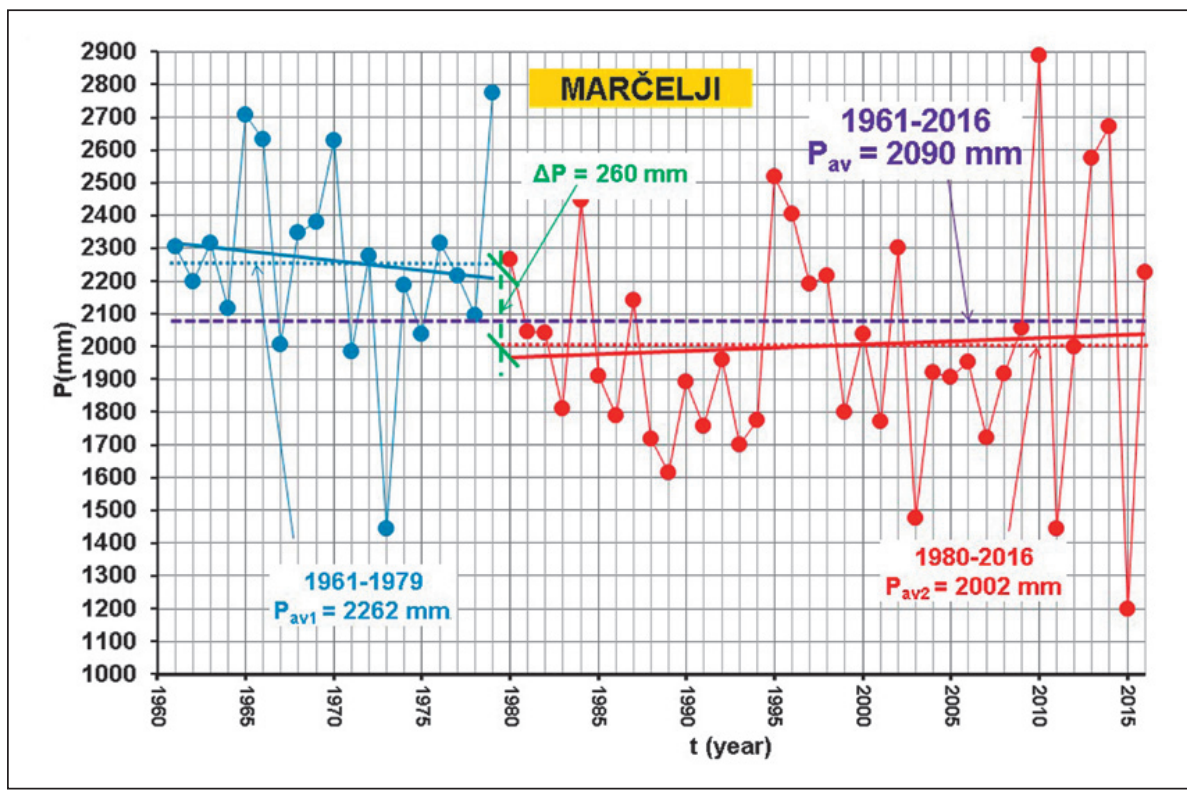

Fig. 3: Mean annual rainfall measured at the Marčelji rain gauging station divided into two time series for periods: (1) 1961-1979 and (2) 1980-2016. Solid lines indicate trend: blue line for the first subperiod, red line for the second.

extremely complex hydrogeological setting in this karst system. The largest number of tracer tests was carried out from intermittent or permanent ponors and some from the boreholes. In Fig. 2 it is possible to see the results of tracings from transboundary Croatian-Slovenian aquifers, too. As tracer tests indicate, a part of groundwater flow from the Grobnik Polje is directed to springs in Rijeka City (Zvir Spring and Zvir 2 Intake gallery) and the other part to the Bakar bay springs (Perilo, Dobra, Dobrica in Fig. 2). In the north-eastern coast of the Bakar Bay there are numerous coastal and submarine permanent and intermittent karst springs. This location represents the lowest placed contact between large karst aquifer and flysch lithogenetic complex that forms hydrogeological barrier (Benac et al. 2003).

Karst system of the Rječina River and Spring is characterized by many endorheic depressions. An endorheic basin (terminal basin or internal drainage system) is a closed drainage basin that retains water and prevents outflow to other external bodies of water (Fiorillo \& Pagnozzi 2014). Recharge of the analysed karst aquifer from these endorheic depressions occurs when rainfall and snowmelt infiltration passes the soil surface and percolates through the vadose zone. The infiltration can occur in both, concentrated and diffuse forms.

The first systematic analysis of the stable isotope composition of the complex karst hydrological systems in the broader area of the Rječina River catchment revealed that: (1) stable isotope composition of the spring water suggests the recharge is dominated by winter precipitation, (2) seasonal variations were not observed in the stable isotope composition of the precipitation, (3) the dual-porosity system is dominated by baseflow (a fissure-porous aquifer), (4) the hinterlands of the indi- vidual springs have different degrees of karstification, (5) stable isotope analyses of groundwater and precipitation suggests a meteoric origin of the groundwater, (6) the isotopic compositions of the baseflow and the rapid-flow components of springs within the Rječina River catchment (especially Rječina Spring) originate at higher elevations than the other springs located outside of the catchment (Mance et al. 2014).

The terrain configuration, with mountains rising steeply just a few kilometres inland from the shores of the Adriatic Sea, provides some striking climatic and landscape contrasts within a small geographic area. The climate of the study area varies between the North Mediterranean (near the Adriatic Sea coast) and mountain (in the upper part, which reaches the altitude of $1000 \mathrm{~m}$ a.s.l.).

Two stations: Marčelji rain gauging station and Rijeka meteorological station were chosen for the rainfall analysis due to the availability of data. Rainfall for the period 1961-2016 and 1948-2016 were available respectively.

The annual rainfall measured at the Marčelji rain gauging station during the 1961-2016 period (Croatian Hydrological and Meteorological Service - DHMZ) varies in a very large range between $1198 \mathrm{~mm}$ (2015) and $2889 \mathrm{~mm}$ (2010). Fig. 3 shows mean annual rainfall measured at the Marčelji rain gauging station divided into two time series: (1) 1961-1979 and (2) 1980-2016. The average annual rainfall for the whole period (1961-2016) is $2090 \mathrm{~mm}$. Two previously mentioned subseries were defined using rescaled adjusted partial sums (RAPS) method (Garbrecht \& Fernandez 1994). A time series analysis can detect and quantify trends and fluctuations in records. The rescaled adjusted partial sums (RAPS) 


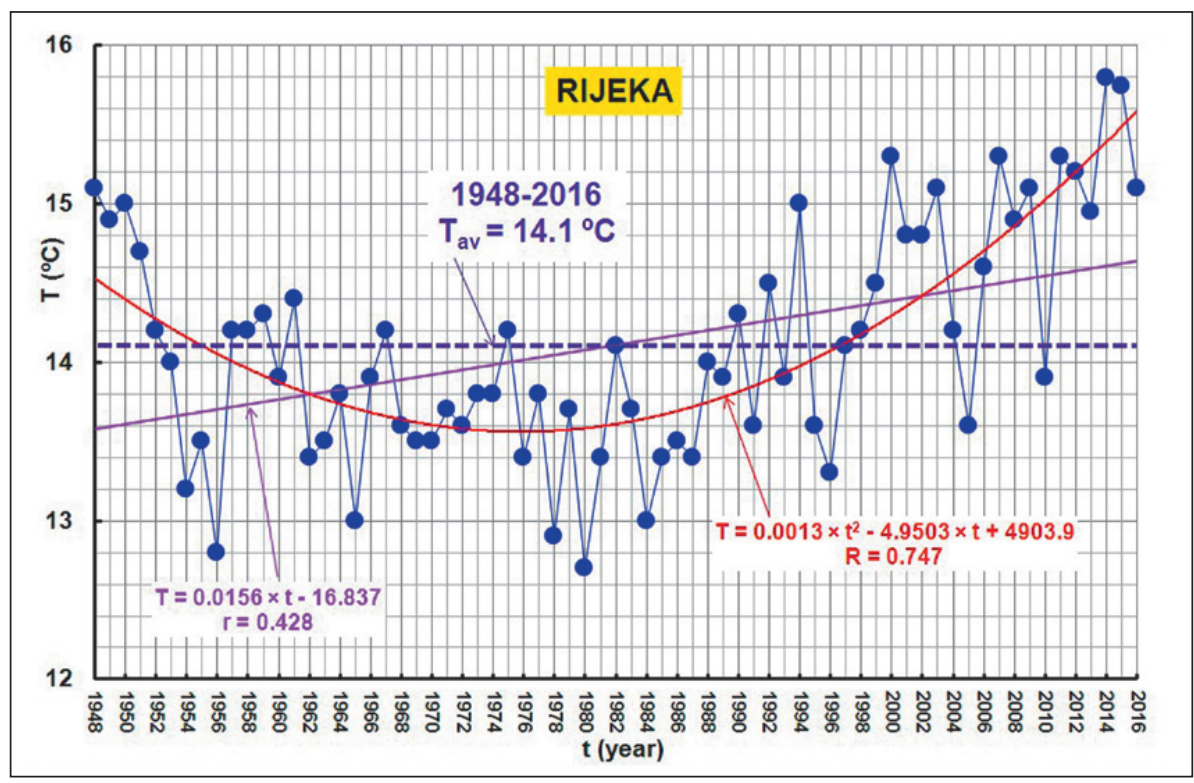

Fig. 4: Time series of the mean annual temperature for the Rijeka meteorological station in the 19482016 period. Solid lines indicate temperature trend: violet line linear trend and red line second-order polynomial trend.

approach highlights small yet systematic changes over time that are often hidden in a standard time series plot by the comparatively large magnitude and variability of data itself (Garbrecht \& Fernandez 1994).

In the first subperiod average annual rainfall was $2262 \mathrm{~mm}$, while in the second it dropped $260 \mathrm{~mm}(12 \%)$ to $2002 \mathrm{~mm}$, which is statistically significant (t-test $\mathrm{p}<0.01)$.

Areal rainfall distribution follows a well-developed topography. The average annual rainfall measured at the Rijeka meteorological station, which is located near the Adriatic Sea coast (Fig. 1), in the 1948-2015 period (DHMZ) was $1547 \mathrm{~mm}$, varying between $1021 \mathrm{~mm}$ (2003) and $2105 \mathrm{~mm}$ (2010). The rainfall in Rječina Spring basin area is abundant with a very high intensity that can reach the value of 100 mm h-1 (Gajić-Čapka et al. 2014).

Fig. 4 depicts a time series of mean annual tempera- ture for the Rijeka meteorological station in the 19482016 period (DHMZ). It includes linear and secondorder polynomial trend lines. The average mean annual air temperature is $14.1^{\circ} \mathrm{C}$. The minimum mean annual air temperature of $12.7^{\circ} \mathrm{C}$ was recorded in 1980 and the maximum of $15.8^{\circ} \mathrm{C}$ in 2014 .

The linear trend is statistically significant $(\mathrm{p}<0.01)$ with a linear correlation coefficient, $r=0.428$. The second-order polynomial trend with a coefficient of nonlinear correlation, $r=0.747$, is much higher. It provides a better fit for the analysed data than the linear one. Fig. 4 shows a strong increasing trend of mean annual air temperatures over approximately last 35 years (started in early 1980s), which could have a strong influence on the Rječina Spring and River hydrological regime, especially in combination with annual rainfall decreases, which started in 1980 (Fig. 3).

\section{HYDROLOGY OF THE RJEČINA SPRING AND RIVER}

\section{THE RJEČINA KARST SPRING HYDROLOGY}

Fig. 5 shows a photography of the Rječina Spring. It should be noted that small concrete dam has been constructed at the spring exit. The top of this dam is at the altitude of $325.24 \mathrm{~m}$ a.s.l.

Knežević (1999) cited that the recharge area of Rječina River covers $163.9 \mathrm{~km}^{2}$. This number represents only a rough estimation. Exact boundaries and catchment area are not yet defined. More recent studies estimate the catchment area to be 2-3 times larger (app. $500 \mathrm{~km}^{2}$ ) than previously presumed (Munda et al. 2009; Kuhta et al. 2014). In order to differentiate the catchment area of coastal springs in Rijeka City from the coastal springs in the Bakar Bay, several tracer tests from Grobnik Polje were performed in the last decade. Rječina Spring catchment should be defined on the basis of detailed interdisciplinary investigations using continuous measurements of different climatologic, geologic, hydrogeologic and hydrologic parameters. At this moment, there is no enough data to fulfil this complex task, extremely important in order to 
protect these valuable karst water resources. It seems that the Rječina River catchment changes in time and space depending on temporal hydrological conditions.

Fig. 6 shows mean annual discharges measured at the Rječina Spring hydrological station during the 1948-2016 period (missing 1960-1965, 2001) (DHMZ). The average annual discharge for the complete analysed period is $6.87 \mathrm{~m}^{3} \mathrm{~s}^{-1}$, ranging between $3.53 \mathrm{~m}^{3} \mathrm{~s}^{-1}$ (2011) and 11.26 $\mathrm{m}^{3} \mathrm{~s}^{-1}$ (1951). Using the RAPS method, the following two subseries with statistically significant average annual discharges are defined: (1) 1948-1979 (missing 1960-1965) and (2) 1980-2016 (missing 2001). The first subperiod shows $1.71 \mathrm{~m}^{3} \mathrm{~s}^{-1}$ (about 25\%) higher average annual discharge than the second subperiod.

Fig. 7 shows two linear regressions between mean annual discharges measured at the Rječina Spring and annual precipitation measured at the Marčelji gauging station during two subperiods: (1) 1966-1979 and (2) 1980-2016 (2001 missing) (DHMZ). High statistically significant values of the coefficients of linear correlation $\left(r_{1}=0.765\right.$ and $\left.r_{2}=0.848\right)$ indicate that the mean annual discharges substantially depend on annual rainfalls in both subperiods. In the first subperiod (1966-1979) the same annual precipitation causes higher Rječina Spring annual discharges than during the second subperiod (1980-2016). For the lower precipitation, these differences are larger than for the higher precipitation. This is shown in Fig. 7: (1) for $\mathrm{P}$ $=1500 \mathrm{~mm}, \Delta \mathrm{Q}_{1}=1.96 \mathrm{~m}^{3} \mathrm{~s}^{-1}$; (2) for $\mathrm{P}=2500 \mathrm{~mm}, \Delta \mathrm{Q}_{2}$ $=0.964 \mathrm{~m}^{3} \mathrm{~s}^{-1}$. Occurrence of two relationships between $\mathrm{P}$ and $\mathrm{Q}$, in two subperiods is caused by natural and anthropogenic factors. Natural factors are increase of air temperature (Fig. 4) and drop in annual precipitations (Fig. 3) during the second subperiod. Anthropogenic influence is caused by the construction of the new pipeline (in 1980) and increased water caption from the Rječina Spring. The main problem is the lack of data that would enable quantification of the impact of both, natural climatic cause as well as human activities on the process.

During the 1948-2016 period (missing 1960-1965 and 2001) (DHMZ) values of the maximum annual discharges range between $31.7 \mathrm{~m}^{3} \mathrm{~s}^{-1}(2007)$ and $62.9 \mathrm{~m}^{3} \mathrm{~s}^{-1}$ (2016) with average of $43.8 \mathrm{~m}^{3} \mathrm{~s}^{-1}$. Although intensive short-time precipitations are frequent in the analysed region maximum discharges emerging from the spring are not extremely high. This karst spring belongs to the springs with limited outflow capacity. There are many factors that limit maximum discharges of karst springs, like the size of the karst conduit, intercatchment overflow, pressure flow and occurrence of intermittent springs in the same catchment (Bonacci 2001; Barberá \& Andreo 2015).

According to the available data (2003-2016, Croatian waters monitoring data base) the minimum measured water temperature at the Rječina spring was $6.6^{\circ} \mathrm{C}$,

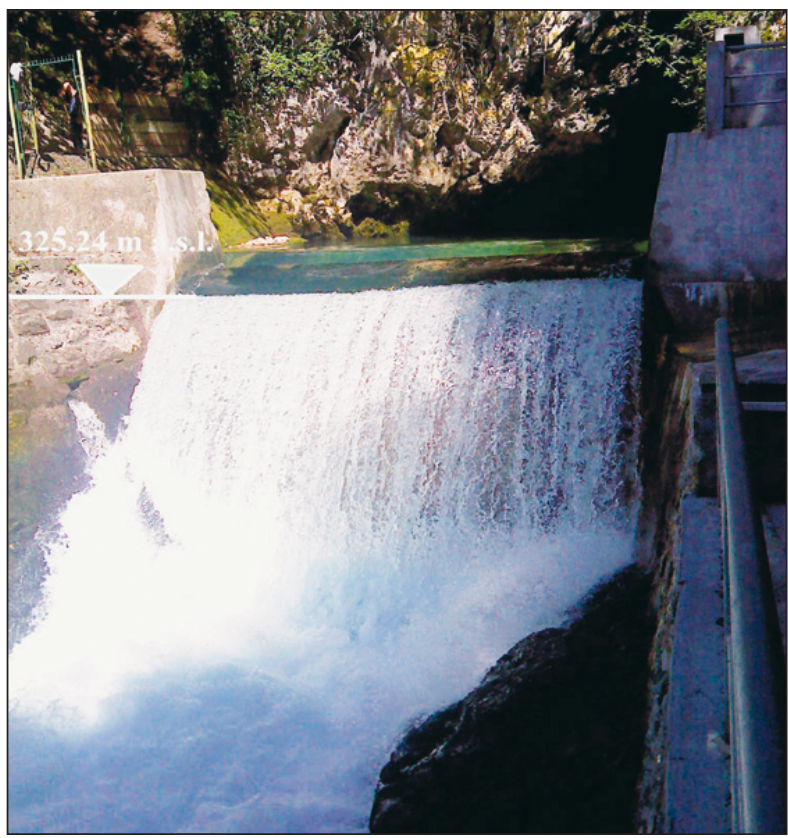

Fig. 5: The dam constructed at the exit of the Riječina spring cave (Photo: VIK Rijeka).

a maximum of $10^{\circ} \mathrm{C}$ with an average value of $7.8^{\circ} \mathrm{C}$. These values clearly indicate that water retains within a deep karst aquifer relatively long and the air temperature in the spring catchment area, that varies in a wide range, has no significant effect on the temperature.

It should be noted that spring can dry up practically any day during the year. Minimum discharges occur during the hot summer period when the demands for the water are the highest. The average value of the days in a year when Rječina Spring dried up in the 1948-2016 period (missing 1960-1965 and 2001) was 44.6 days, and it ranges between $0(1948,1968,1977,2014)$ and 157 days (1949) (Bonacci et al. 2017). When the Riječina spring dries out, water from the Zvir Spring is used for the water supply.

Besides the Rječina Spring, that covers approx. 75\% of water needs of the Rijeka City and the surrounding area, there are several other springs and wells used for water supply. During the 1997-2015 period, between 13.4 $\times 10^{6} \mathrm{~m}^{3}(2007)$ and $20.9 \times 10^{6} \mathrm{~m}^{3}$ (2014) of water of high quality was used yearly from the Rječina Spring, with an average of $17.7 \times 10^{6} \mathrm{~m}^{3}$, that is app. $560 \mathrm{l} / \mathrm{s}$ (Bonacci et al. 2017).

\section{RJEČINA RIVER HYDROLOGY}

There are seven hydrological stations at the relatively short Rječina River watercourse $(18.5 \mathrm{~km})$. Despite that fact, it is not possible to make detailed and reliable hydrological analyses, due to the gaps in measurements and end of operation of two stations. The river hydrological regime downstream of the Valići Dam (river km 11.9) 

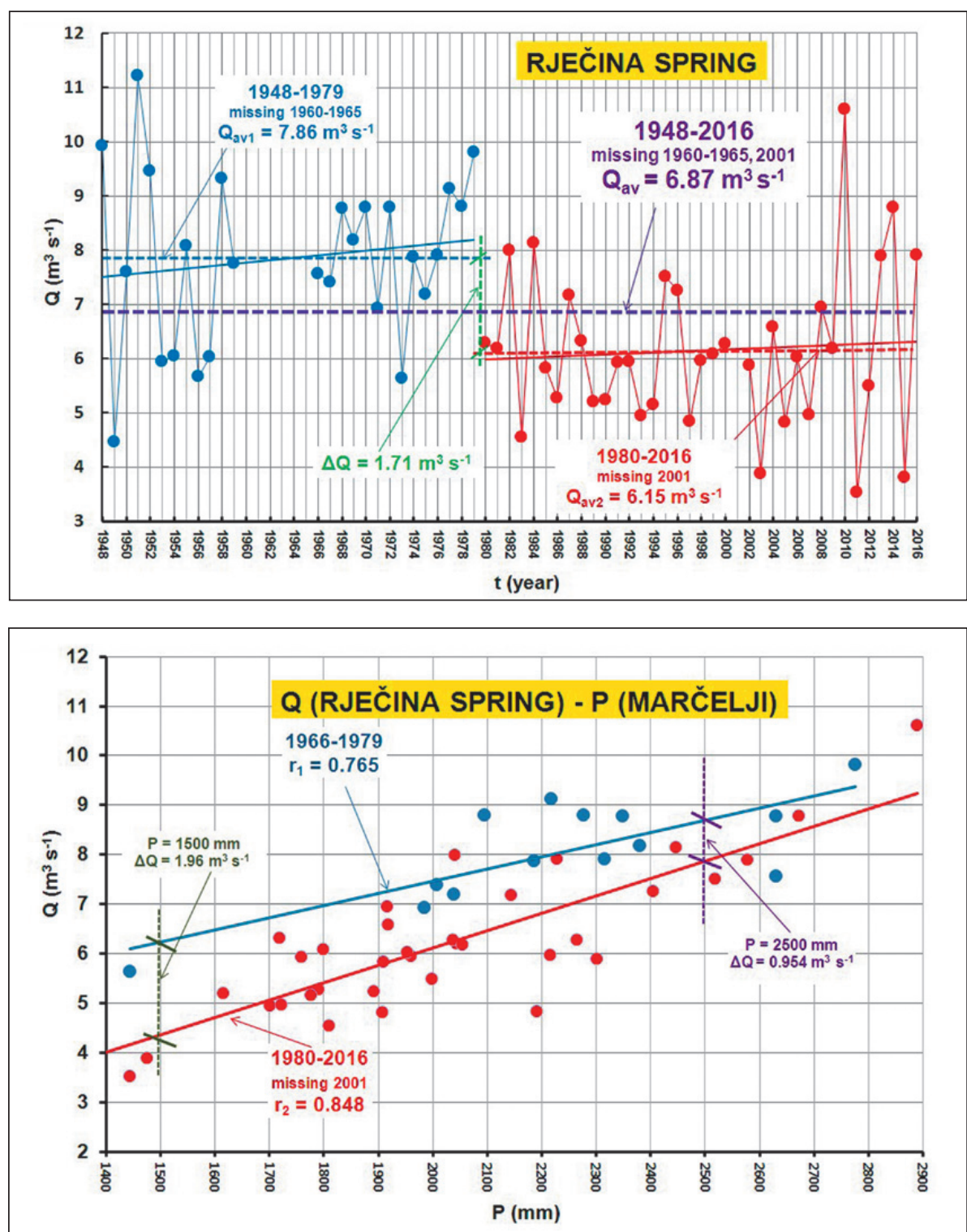

Fig. 6: Mean annual discharges measured at the hydrological station Rječina Spring divided into two time series for periods: (1) 1948-1979 (missing 1960-1965) and (2) 1980-2016 (missing 2001). Solid lines indicate trend: blue line for the first subperiod, red line for the second.

Fig. 7: Linear regressions between mean annual discharges, $Q\left(\mathrm{~m}^{3} \mathrm{~s}\right.$ $\left.{ }^{1}\right)$, measured at Rječina Spring and annual precipitation, $P(\mathrm{~mm})$, measured at the Marčelji gauging station during two subperiods: (1) 1966-1979 and (2) 1980-2016 (missing 2001). is completely and drastically changed. From the HEPP Rijeka water returns in the Rječina River course app. 1 $\mathrm{km}$ before its mouth to the Adriatic Sea (river km 17.5). Ecological as well as other consequences of drastic natural river regime changes at about $5.6 \mathrm{~km}$ river section has not been investigated well enough until now. Fig. 8 represents a longitudinal profile of the Rječina River watercourse showing locations of seven hydrologic gauging stations, the Valići Dam and Reservoir and planned dam and reservoir Kukuljani.

The Rijeka hydroelectric power plant (HEPP) is a high-pressure diversion HEPP constructed at the Rječina River watercourse. Valići Reservoir with active storage of $470,000 \mathrm{~m}^{3}$ was formed by construction of $35 \mathrm{~m}$ high concrete gravity dam upstream from the village of Grohovo. Photography of the dam is given in Fig. 9. Maxi- mum operating reservoir water level is $229.5 \mathrm{~m}$ a.s.l. The installed discharge is $21 \mathrm{~m}^{3} \mathrm{~s}^{-1}$. The Rijeka HEPP was put into its full operation at the end of 1968. Its construction and operation strongly and instantaneously influenced the Rječina River regime downstream.

Fig. 10 shows mean annual discharges measured at the Grohovo hydrologic station during the 1947-2016 period (missing 1976-1979, 1995-1997, 2000-2001, 2007, 2012-2014). This station is located downstream of the Valići Reservoir. Before the operation of the Rijeka HEPP (1947-1968) average annual discharge was $9.12 \mathrm{~m}^{3} \mathrm{~s}^{-1}$. Its construction caused strong drop in average annual discharges of $7.48 \mathrm{~m}^{3} \mathrm{~s}^{-1}(82 \%)$. After the dam construction in 1969-2016 period, average annual discharge is only $1.64 \mathrm{~m}^{3} \mathrm{~s}^{-1}$.

Tab. 1 provides basic information for seven hydro- 


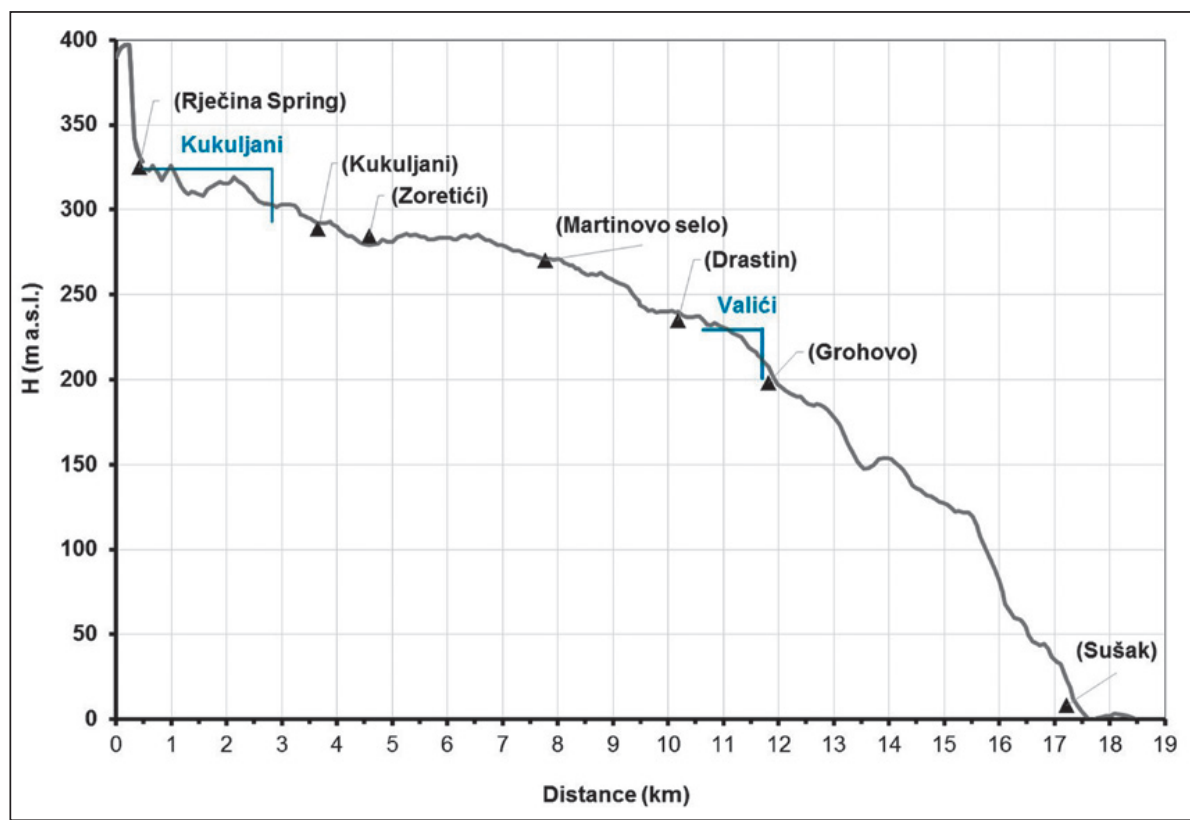

Fig. 8: Longitudinal profile through the Rječina River with indicated locations of Kukuljani and Valići Dams and Reservoirs and seven hydrological gauging stations.

logic stations along the Rječina River. The first five stations (Rječina Spring, Kukuljani, Zoretići, Martinovo selo and Drastin) are located upstream of the Valići Reservoir, while the last two (Grohovo and Sušak) are located downstream. It is discernible from the data given in the Tab. 1 that there are many monitoring gaps.

Therefore, in the last four table rows average mean annual discharges along the Rječina River in four different subperiods are given: (1) 1949-1958, (2) 1966-1968, (3) 1969-1973 and (4) 1990-2015 (missing 2000-2001, 2006-2014). The first two subperiods represent the natural state of the river hydrological system, while in the last two subperiods an obvious influence of the Rijeka HEPP is evident.

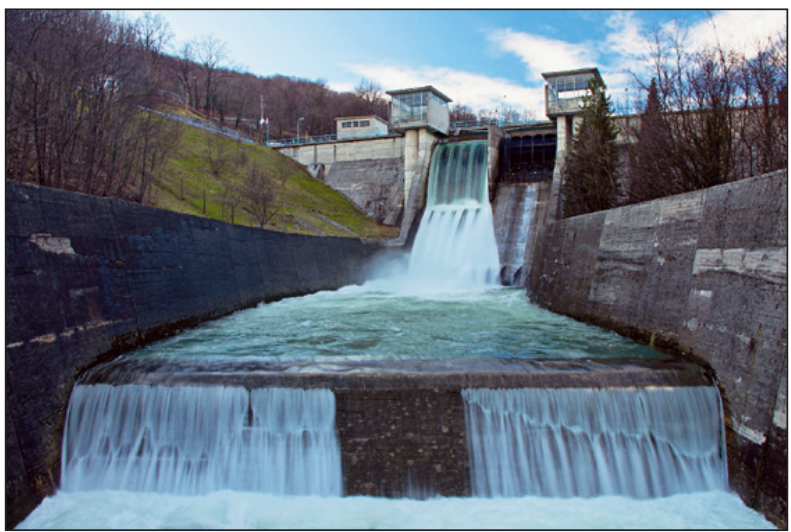

Fig. 9: The Valići Dam (Photo: D. Ban).

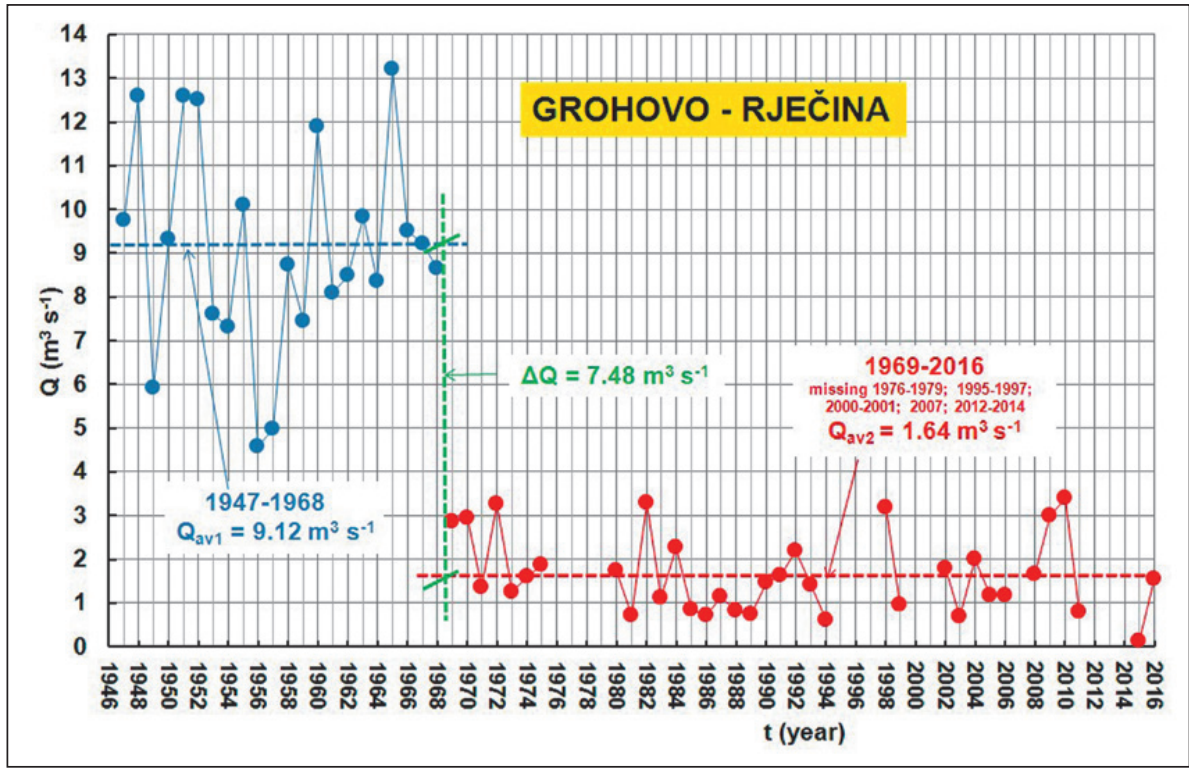

Fig. 10: Mean annual discharges measured at the Grohovo hydrologic station divided into two time series for periods (1) 1947-1968 and (2) 1968-2016 (missing 1976-1979, 1995-1997, 2000-2001, 2007, 20122014). 
Tab. 1: Characteristics of hydrological gauging stations along the Rječina River in four different subperiods.

\begin{tabular}{|c|c|c|c|c|c|c|c|c|}
\hline \multicolumn{2}{|c|}{ Station name } & $\begin{array}{l}\text { Rječina } \\
\text { Spring }\end{array}$ & Kukuljani & Zoretići & $\begin{array}{l}\text { Martinovo } \\
\text { selo }\end{array}$ & Drastin & Grohovo & Sušak \\
\hline \multicolumn{2}{|c|}{$\begin{array}{l}\text { Elevation } \\
\text { (m a.s.I.) }\end{array}$} & 325.214 & 288.720 & 284.240 & 273.046 & 234.761 & 194.315 & 2.069 \\
\hline \multicolumn{2}{|c|}{ Start of operation } & 1.1.1948 & 17.1.1946 & 1.6.1987 & 24.9.1964 & 1.6.1986 & 18.10.1946 & 1.6.1948 \\
\hline \multicolumn{2}{|c|}{ End of operation } & - & 31.12. 1975 & - & - & - & - & 4.12.1966 \\
\hline \multicolumn{2}{|c|}{ Missing year } & $\begin{array}{c}1960-1965 \\
2001\end{array}$ & - & - & $\begin{array}{c}2000,2007- \\
2014\end{array}$ & $\begin{array}{c}2010,2012 \\
2014\end{array}$ & $\begin{array}{c}1976-1979, \\
1995-1997,2000- \\
2001,2007,2012- \\
2014 . \\
\end{array}$ & - \\
\hline \multirow{4}{*}{$\begin{array}{l}Q \\
\left(\mathrm{~m}^{3}\right. \\
\left.\mathrm{s}^{-1}\right)\end{array}$} & $\begin{array}{l}1949- \\
1958\end{array}$ & 7.41 & 7.88 & - & - & - & 8.36 & 11.9 \\
\hline & $\begin{array}{l}1966- \\
1968\end{array}$ & 7.9 & 7.9 & - & 8.43 & - & 9.12 & 13.7 \\
\hline & $\begin{array}{c}1969- \\
1973\end{array}$ & 7.63 & 8.32 & - & 7.64 & - & 2.33 & - \\
\hline & $\begin{array}{c}1990- \\
1999 \\
2002- \\
2005 \\
2015-2016\end{array}$ & 5.79 & - & 6.40 & 6.62 & 7.97 & $* 1.42$ & - \\
\hline
\end{tabular}

\section{GROUNDWATER IN THE CATCHMENT AREA}

Piezometers represent an exceptionally important source of wide-range information, necessary for all types of investigations related to the regime of water circulation in karst. In the studied area eleven deep piezometer boreholes were drilled, in the period of app. 30 years, in order to provide better understanding of groundwater behaviour and the hydrogeology of the area. Fig. 1 shows locations of 9 analysed (P1, P2, P2B, P3, P4, P5; B1, B2, B3) piezometers. Groundwater monitoring was performed in three periods: (1) 1974-1986, (2) 1994-1996 and (3) 2012-2013. We analysed only the last two periods, because only these data (Biondić et al. 1997, Kuhta et al. 2014) were available to the authors. In the first period (1994-1996), portable meters were used for measurements of water levels every three days, and for measurements of temperature and conductivity once in a month. In the second period, water level data loggers (HOBO Water Level Logger, Onset computers) were installed in the boreholes and continuous water level and temperature measuring was carried out in two hour intervals.

Tab. 2 provides characteristics of seven piezometers measured during the second period (1994-1996) (Biondić et al. 1997). Tab. 3 is a matrix of the coefficient of linear correlation between groundwater levels measured at seven piezometers during the same period (1994-1996). From the data given in both tables, it is possible to conclude that groundwater in different piezometers reacts individually, yet homogeneously in the whole analysed system. For example, in P1 the groundwater level ranges only $27.55 \mathrm{~m}$, while in piezometer P2 it ranges $122.35 \mathrm{~m}$, which is app. 4.5 times higher. At the same time, the coefficient of linear correlation between groundwater levels of these two piezometers is statistically significant, $r=$ 0.762 .

Extremely different groundwater reaction in piezometers, drilled within a small distance, less than $10 \mathrm{~m}$ away from each other, is common in karst environment (Drogue 1980, 1985; Bonacci \& Roje-Bonacci 2012). Piezometers connected to active karst conduits react more rapidly than piezometers drilled in a karst matrix.

Tab. 4 provides characteristics of five piezometers measured during the third period (2012-2013) (Kuhta et al. 2014). Fig. 11 shows time series of the groundwater level measured at those five piezometers and discharges of the Rječina Spring (modified from Kuhta et al. 2014). It should be mentioned, that piezometer $\mathrm{P} 2 \mathrm{~B}$ was drilled in 2005, just $10 \mathrm{~m}$ from the existing piezometer P2 that was measured in the second period. New piezometer $\mathrm{P} 2 \mathrm{~B}$ was drilled due to the intensive dynamics of groundwater level measured in P2 in the second period. Most of the existing piezometers were not fully penetrable as they were in the first and second period, so water level data loggers could not be installed at a proper depth. This is the reason why the lowest groundwater levels could not be measured (B1, B3 in Fig. 10, Tab. 4). 
Tab. 2: Characteristics of piezometers measured during the second period (1994-1995).

\begin{tabular}{|l|c|c|c|c|c|c|c|}
\hline & P1 & P2 & P3 & P4 & P5 & B1 & B2 \\
\hline $\begin{array}{l}\text { Elevation of the } \\
\text { borehole mouth } \\
\text { (m a.s.I.) }\end{array}$ & 580 & 524 & 518 & 550 & 505 & 332 & 295 \\
\hline Start of operation & 15.08 .1994 & 18.12 .1994 & 11.03 .1995 & 01.05 .1995 & 21.07 .1995 & 15.08 .1994 & 15.8 .1994 \\
\hline End of operation & 30.12 .1996 & 30.12 .1996 & 30.12 .1996 & 30.12 .1996 & 29.12 .1996 & 02.12 .1996 & 30.11 .1996 \\
\hline $\mathrm{H}_{\min }$ (m a.s.I.) & 469.20 & 352.75 & 358.44 & 404.90 & 410.44 & 241.01 & 232.83 \\
\hline $\mathrm{H}_{\max }(\mathrm{m}$ a.s.I.) & 496.75 & 475.10 & 499.90 & 503.20 & 442.80 & 323.00 & 295.00 \\
\hline $\mathrm{H}_{\max }-\mathrm{H}_{\min }(\mathrm{m})$ & 27.55 & 122.35 & 141.46 & 98.3 & 32.36 & 81.99 & 62.17 \\
\hline
\end{tabular}

\begin{tabular}{|l|c|c|c|c|c|c|c|}
\hline$r$ & $P 1$ & $P 2$ & $P 3$ & $P 4$ & $P 5$ & $B 1$ & B2 \\
\hline P1 & 1 & 0.762 & 0.584 & 0.618 & 0.811 & 0.450 & 0.660 \\
\hline P2 & & 1 & 0.862 & 0.685 & 0.536 & 0.629 & 0.711 \\
\hline P3 & & & 1 & 0.825 & 0.584 & 0.613 & 0.615 \\
\hline P4 & & & & 1 & 0.715 & 0.434 & 0.392 \\
\hline P5 & & & & & 1 & 0.699 & 0.600 \\
\hline B1 & & & & & & 1 & 0.797 \\
\hline B2 & & & & & & & 1 \\
\hline
\end{tabular}

Tab. 3: Matrix of coefficient of linear correlation between groundwater levels measured during the second period (1994-1996).

The groundwater in the piezometer $\mathrm{P} 1$ above Rječina Spring (325.24 $\mathrm{m}$ a.s.l.) is active in all hydrological conditions, even during the summer period when Rječina Spring dried out (middle of July - middle of September 2013). This indicates that P1 does not measure or represents the actual groundwater level in the aquifer, but local changes in groundwater due to the local influence. Groundwater levels in piezometer P2B act similar as in piezometer P1. It is visible that the level of P2B started a gradual decrease from June 2013 with a sudden drop of app. $40 \mathrm{~m}$ in August followed with the sudden increase after an insignificant rainfall in the end of August. This sudden increase was not followed by the increase of Rječina spring discharge. This leads to a conclusion that $\mathrm{P} 2 \mathrm{~B}$ is drilled in rocks of lower permeability. Comparing the data from Tab. 2 and 4, it is obvious that groundwater level oscillations are different for P2B and P2, although they are located within a $10 \mathrm{~m}$ distance. All other piezometers show similar range of groundwater level measured in those two different periods. Tab. 5 is a matrix of the coefficient of linear correlation between groundwater levels measured at five piezometers during the third peri-

Tab. 4: Characteristics of piezometers measured during the third period (2012-2013).

\begin{tabular}{|l|c|c|c|c|c|}
\hline & P1 & P2B** & B1 & B2 & B3 \\
\hline $\begin{array}{l}\text { Elevation of the borehole mouth } \\
(\mathrm{m} \text { a.s.I.) }\end{array}$ & 580 & 523 & 325 & 295 & 320 \\
\hline Start of operation & 02.10 .2012 & 02.10 .2012 & 01.10 .2012 & 01.10 .2012 & 01.10 .2012 \\
\hline End of operation & 15.10 .2013 & 15.10 .2013 & 17.4 .2013 & 15.10 .2013 & 15.10 .2013 \\
\hline Water temperature $\left({ }^{\circ} \mathrm{C}\right)$ & 9.18 & $9.28-9.77$ & $8.38-8.78$ & $7.98 .-8.48$ & $7.28-7.78$ \\
\hline Diver depth $(m$ a.s.I.) & 474.12 & 327.70 & 250.24 & 219.16 & 265.73 \\
\hline $\mathrm{H}_{\min }(\mathrm{m}$ a.s.I.) & 469.31 & 371.04 & $*$ & 232.75 & $*$ \\
\hline $\mathrm{H}_{\max }(\mathrm{m}$ a.s.I.) & 502.34 & 432.98 & 316.27 & 294.85 & 305.10 \\
\hline $\mathrm{H}_{\max }-\mathrm{H}_{\min }(\mathrm{m})$ & 33.03 & 61.94 & - & 62.10 & \\
\hline
\end{tabular}

* groundwater level below the measuring instrument; ** piezometer drilled in 2005

\begin{tabular}{|l|c|c|c|c|c|}
\hline$r$ & P1 & P2B & B1 & B2 & B3 \\
\hline P1 & 1 & 0.539 & 0.611 & 0.682 & 0.574 \\
\hline P2B & & 1 & 0.484 & 0.548 & 0.462 \\
\hline B1 & & & 1 & 0.949 & 0.982 \\
\hline B2 & & & & 1 & 0.858 \\
\hline B3 & & & & & 1 \\
\hline
\end{tabular}

Tab. 5: Matrix of coefficient of linear correlation between groundwater levels measured during the third period (2012-2013). 

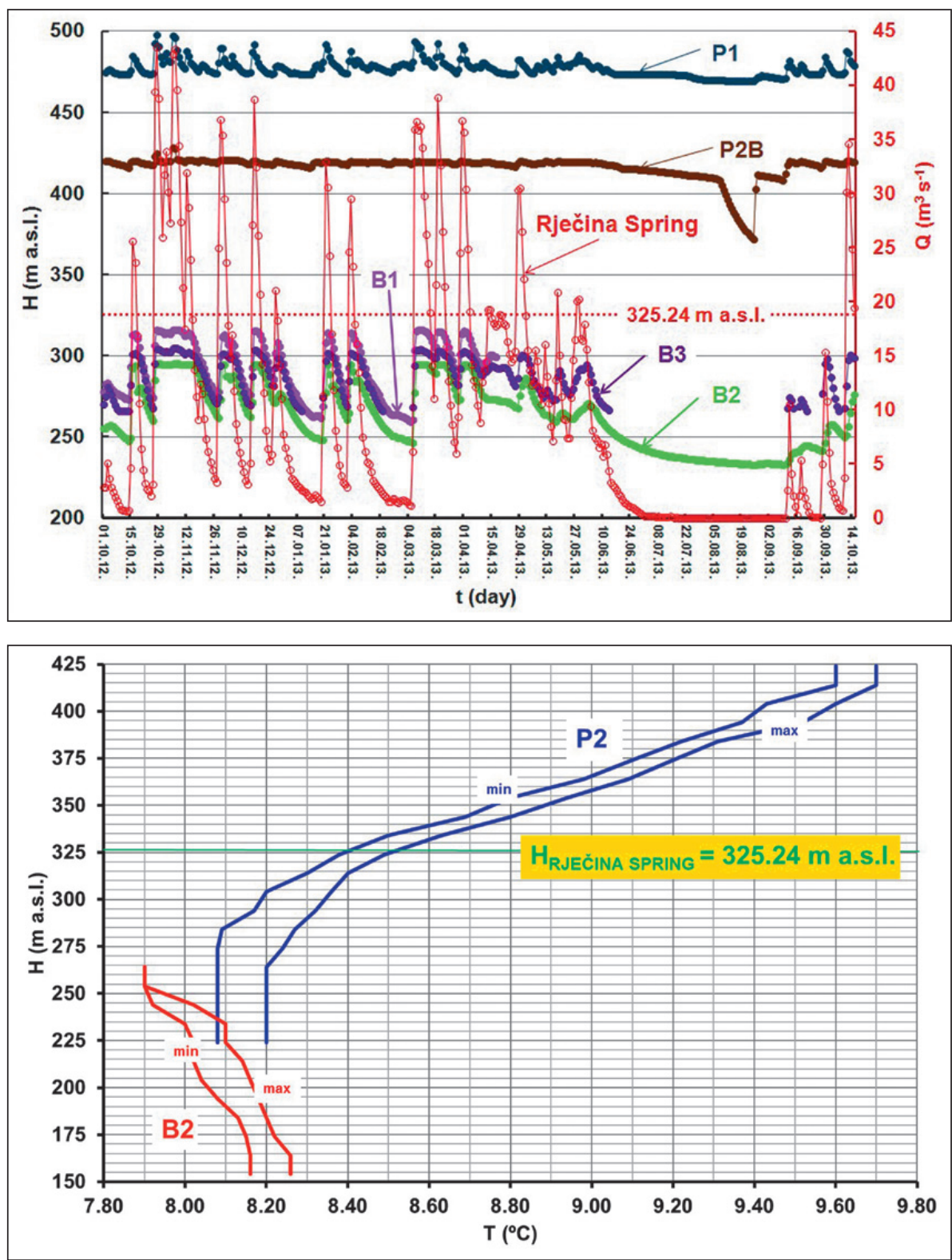

Fig. 11: Groundwater level measured at five deep piezometers located in the Rjecina River catchment in the third period (2012-2013) and discharges of the Rječina Spring (modified from Kuhta et al. 2014).
Fig. 12: Graphical presentation of the groundwater temperature measured monthly in two piezometers (P2 and B1 in Fig. 1) (modified from Biondić et al. 1997). od (2012-2014). The conclusion is practically the same as in the previous case for measurements during the second period (1994-1996).

Because of steep terrain configuration, groundwater has intensive flowing gradient. Due to highly developed surface and underground karst forms the catchment area recharges and stores deep circulating water with high storage capacity.

Fig. 12 represents the groundwater temperature in piezometers P2 and B1 (Biondić et al. 1997) measured monthly in the period 1994-1996. The temperature in piezometer P2, located at a higher altitude than Rječina Spring, has a constant decrease downwards approaching to the spring water temperature. The piezometer B1 located in the Grobnik Polje at a lower altitude than
Rječina Spring showed different behaviour. The groundwater temperature constantly increases.

Using thermal signatures, Doucette \& Peterson (2014) delineate flow components in the karst aquifer of the springs Copperhead and Langle (Northwest Arkansas, USA). They revealed three distinct reservoirs (epikarst, shallow groundwater and deep groundwater), which have different thermal relationships with the air temperature. During a more humid period, the epikarst water temperatures follow the air temperature trend more closely. During drier conditions, the shallow groundwater temperatures are more similar to air temperature. Deep groundwater temperatures show no relationship to variations in surface air temperature. In our case (see Tab. 4) the temperatures of groundwater 
measured on the same depth (installed loggers for measuring water levels) showed range within $0.5^{\circ} \mathrm{C}$ during period of measurement (October 2012- October 2013) with the exception of $\mathrm{P} 1$ where constant temperature was measured during the period. Data in Tab. 4 indicate deep groundwater temperatures with no variations with surface air temperature.

Values of electrical conductivity measured in piezometer $\mathrm{P} 2$ change in narrow range between 270 and $287 \mu \mathrm{S} \mathrm{cm}^{-1}$, and have decreasing trend from the surface to the deep underground (Biondić et al. 1997). Hundred meters below the surface, electrical con- ductivity is around $17 \mu \mathrm{S} \mathrm{cm}^{-1}$ (or around 6\%) lower than near the surface. Decrease of electrical conductivity with depth indicates lower salt content, that is faster flow. The higher the water hardness, the greater its electrical conductivity is. Bakalowicz \& Mangin (1980) measured the electrical conductivity of water of several karst springs recharged from the deep karst aquifer. The values ranged between 220 and $470 \mu \mathrm{S}$ $\mathrm{cm}^{-1}$. Electrical conductivity of water emerging from Jadro Spring (Croatia) ranged between 250 and $350 \mu \mathrm{S}$ $\mathrm{cm}^{-1}$, and of water in the Blue Lake (Croatia) between 301 and $438 \mu \mathrm{S} \mathrm{cm}^{-1}$ (Bonacci et al. 2013).

\section{CONCLUSIONS}

The analysis of climatic data indicates an increasing trend of air temperature and a decreasing trend of rainfall in the analysed region. The reduction of rainfall, the temperature and consequently evapotranspiration increase and the future anthropogenic interventions will strongly and dangerously affect Rječina Spring and the Rječina River water availability. The need for a better understanding of the impact of the development of the Rijeka HEPP and new pressures is of crucial importance.

Despite great scientific efforts and fast technological development, scientist and engineers still have not been able to reliably foresee mostly dangerous consequences of very different human activities in karst terrains. Some of them occurred instantaneously but some emerge after long time (years or decades). Vulnerable karst ecosystems and environment are more prone to those dangerous and difficultly predictable consequences.

Analysing hydrological changes within the karst aquifer (Lurbach system, Austria) Mayaud et al. (2016) concluded that the observed changes are caused by changes within the karst system due to the modification of hydraulic conductivity and storage within the conduit network. They concluded that very probably the main reason is the plugging of the drainage conduits with sediments rather than by varying hydro-meteorological conditions. Process of plugging and clogging of karst conduits is a highly dynamic natural process, which cannot be controlled. Due to this fact scientist and engineers rarely consider it. Anthropogenic interventions can substantially influence the above mentioned natural process. Very probably these processes exist in the Rječina Spring and River karst aquifer, but problem is that our knowledge about them is insufficient.

Groundwater extractions through three controlled locations (Rječina Spring, Zvir Spring and Zvir 2 Intake gallery) of $23.8 \times 10^{6} \mathrm{~m}^{3}$ per year (average in the 19972015 period, that is app. $755 \mathrm{l} / \mathrm{s}$ average daily for the same period) from the karst aquifer can cause the groundwater level to fall. Because of an insufficient number of deep piezometers and short monitoring period it is not possible to precisely define the value and range of the groundwater decrease.

In order to ensure sustainable development of a broader basin area of the Rječina River, its surface and the groundwater quantities and levels should be continuously monitored, in more river profiles and with many more deep piezometers than today. This would be of special importance due to the plans to construct new Kukuljani HEPP. Moreover, it is realistic to expect that the use of the groundwater will increase in the near future, especially during the tourist season.

Assessment of the groundwater recharge potential zone and definition of the Rječina Spring and River catchment areas are extremely important for the effective management of groundwater systems, sustainable development of environment and society.

Because of the fact that the Rječina River headwater is extremely important for the water supply and ecology of a larger densely populated region, this area of a relatively small extension should be more intensely studied and managed. Naturally, the variability of climate in mountain areas is high. It should be taken into consideration that in mountain areas the impact of climate change on water resources is very uncertain and variable (Buytaert \& De Bièvre 2013).

Calò \& Parise (2006) stress that "Determining the karst disturbance can be very difficult because of the inherent complexity of karst systems and subjective because it requires interpretation of the karst environment by the experts, depending upon their dif- 
ferent background." In complex karst surface and underground environment settings, the combined use of geophysical imaging, surface waters hydrological analysis, groundwater measurements (water level, water temperature, electrical conductivity etc.), geochemical measurements, and tracing techniques can provide insights into the local karst hydrology and groundwater processes.
As the evidence suggests, it is realistic to expect that the occurrence of water shortage in the nearby future will be much more frequent and severe. The conflicts between water supplies and environment will be stronger. Better understanding of complex interrelations between surface water and groundwater, as well as the influence of designed anthropogenic actions, can help in negative consequences mitigation (Dragoni et al. 2015).

\section{REFERENCES}

Bakalowicz, M. \& A. Mangin, 1980: L’aquifère karstique. Sa définition, ses caractéristiques et son identification.- Mémoires Hydrogéologique Série Société Géologique de France, 11, 71-79.

Ban, D., 2013: Brana Valići za vrijeme velikog vodostaja: [Online] Available from: https://www.flickr.com/ photos/150439487@N03/33698666113/in/photostream/ [Accessed 3rd March 2018].

Barberá, J.A. \& B. Andreo, 2015: Hydrogeological processes in a fluviokarstic area inferred from the analysis of natural hydrogeochemical tracers: The case study of eastern Serranía de Ronda (S Spain).- Journal of Hydrology, 523, 500-514. DOI: 10.1016/j.jhydrol.2015.01.080

Benac, Č., Rubinić J. \& N. Ožanić, 2003: The origin and evolution of coastal and submarine springs in Bakar Bay.- Acta Carsologica, 32/1, 157-171.

Benac, Č., Dugonjić, S., Vivoda. M., Oštrić, M. \& Ž. Arbanas, 2011: A complex landslide in the Rječina Valley: results of monitoring 1998-2010.- Geologia Croatica, 64, 3, 239-249. DOI: 10.4154/GC.2011.20

Biondić, B., Dukarić, F., Kuhta, M. \& R. Biondić, 1997: Hydrogeological exploitation of the Rječina river spring in the Dinaric karst.- Geologia Croatica, 50, 2, 279-288.

Bonacci, O., 2001: Analysis of the maximum discharge of karst springs.- Hydrogeology Journal, 9, 4, 328-338. DOI:10.1007/s100400100142

Bonacci, O., \& T. Roje-Bonacci, 2012: Impact of grout curtains on karst groundwater behaviour: an example from the Dinaric karst.- Hydrological Processes, 26, 18, 2765-2772. DOI:10.1002/hyp.8359

Bonacci, O., Andrić, I. \& Y. Yamashiki, 2013: Hydrology of Blue Lake in the Dinaric karst.- Hydrological Processes, 28, 4, 1890-1898. DOI:10.1002/hyp.9736

Bonacci, O., Oštrić, M. \& T. Roje-Bonacci, 2017: Prilog hidrologiji krškog izvora Rječine.- Hrvatske Vode, $25,100,99-108$.
Brkić, Ž., Kuhta, M. \& T. Hunjak, 2018: Groundwater flow mechanism in the well-developed karst aquifer system in the western Croatia: Insights from spring discharge and water isotopes.- Catena 161, 14-26.

Buytaert, W. \& B. De Bièvre, 2013: Assessing climate change impacts on water resources in remote mountain regions.- Geophysical Research Abstracts, 15, EGU2013-10412.

Calò, F. \& M. Parise, 2006: Evaluating the human disturbance to karst environments in southern Italy.- Acta Carsologica, 35/2, 47-56.

Doucette, R. \& E.W. Peterson, 2014: Identifying water sources in a karst aquifer using thermal signatures.Environmental Earth Sciences, 72, 12, 5171-5182. DOI:10.1007/s12665-014-3387-2

Dragoni, W., Giontella, C., Melillo, M., Cambi, C., Di Matteo, L. \& D. Valigi, 2015: Possible response of two water systems in Central Italy to climatic changes.- In: Moramarco, T., Barbetta, S. \& L. Brocca, (eds) Advances in watershed hydrology. Water Resources Publications, pp. 397-424, Highlands Ranch, USA

Drogue, C., 1980: Essai d'identification d'un type de structure de magasins carbonates fissures.- Mémoires Hydrogéologique Série Société Géologique de France, 11, 101-108.

Drogue, C., 1985: Geothermal gradients and ground water circulation in fissured and karstic rocks: the role played by the structure of the permeable network.Journal of Geodynamics, 4, 219-231.

Fiorillo, F. \& M. Pagnozzi, 2014: Recharge processes of karst massifs: examples from Southern Italy.- In: Andreo, B., Carrasco, F., Durán, J.J., Jiménez, P. \& J.W. LaMoreaux, (eds) Hydrogeological and environmental investigations in karst systems. Springer, pp. 103-111, Berlin, Heidelberg.

Ford, D.C. \& P.W. Williams, 2007: Karst hydrogeology and geomorphology.- John Wiley \& Sons, Chichester, $562 \mathrm{pp}$. 
Gajić-Čapka, M., Ožanić, N. \& N. Krvavica, 2014: Estimation of maximum short-term precipitation over the Rijeka region.- E-journal Civil Engineering Faculty, Osijek University, 5, 9, 49-59. DOI:10.13167/2014.9.6

Garbrecht, J. \& G.P. Fernandez, 1994: Visualization of trends and fluctuations in climatic records.- Water Resources Bulletin, 30, 2, 297-306.

Goldscheider, N., 2005: Karst groundwater vulnerability mapping: application of a new method in the Swabian Alb, Germany.- Hydrogeology Journal, 13, 4, 555-565.

Knežević, R., 1999: Osnovne značajke režima porječja Rječine.- Acta Geographica Croatica ,34, 73-88.

Kogovšek, J., 2011: Threats to the karst water sources from traffic in normal conditions.- In: Knez, M. et al. (eds), Karstology And Development Challenges On Karst I - Water. Karst Research Institute ZRC SAZU, Postojna, pp. 47-64.

Kuhta, M., Brkić, Ž. \& L. Kuhta, 2014: Izvor Rječine $i$ sjeverozapadni rub Grobničkog polja: hidrogeološki radovi-hidrokemijska i izotopna istraživanja. Croatian Geological Survey, Unpublished study, Zagreb. Report number:010/14.

Mance, D., Hunjak, T., Lenac, D., Rubinić, J. \& Z. Roller-Lutz, 2014: Stable isotope analysis of the karst hydrological systems in the Bay of Kvarner (Croatia).- Applied Radiation and Isotopes, 90, 23-34. DOI:10.1016/j.apradiso.2014.03.001
Mayaud, C., Wagner, T., Benischke, R. \& S. Birk, 2016: Understanding changes in the hydrological behaviour within a karst aquifer (Lurbach system, Austria).- Carbonates and Evaporites, 31, 4, 357-365. DOI:10.1007/s13146-013-0172-3

Munda, B., Trutin, M. \& D. Pribeg, 2009: Novelacija granica zaštitnih zona vodocrpilišta riječkog vodoopskrbnog sustava.- GeoAqua, Unpublished study, Zagreb.

Parise, M. \& J. Gunn (eds.), 2007: Natural and Anthropogenic Hazards in Karst Areas: Recognition, Analysis and Mitigation. Special Publications Vol. 279. Geological Society, pp. 202, London. DOI: 10.1144/ SP279.

Petrič, M., Ravbar, N. \& J. Kogovšek, 2011: Characteristics of karst aquifers, their vulnerability and endangerment.- In: Knez, M. et al. (eds), Karstology And Development Challenges On Karst I - Water. Karst Research Institute ZRC SAZU, Postojna, pp. 7-19.

Velić. I. \& I. Vlahović, 2009: Geological map of the Republic of Croatia 1:300.000. Croatian Geological Survey, Zagreb.

Zupan Hajna, N., Mihevc, A. \& M. Prelovšek, 2010: Land use.- In: Zupan Hajna, N. et al. (eds), Introduction To The Dinaric Karst. Karst Research Institute at ZRC SAZU, Postojna. 